\title{
David Oliver: Covid-19 has made news out of old news
}

\author{
David Oliver consultant in geriatrics and acute general medicine
}

Berkshire

The coronavirus pandemic has brought many health and social care issues to the fore. It's really struck me that many issues that were already clear to health professionals before the pandemic have now become news, when previously they struggled for attention outside specialist healthcare publications. Things that were already essentially good and often mainstream practice before the pandemic are now presented as bad.

Already, it was a good idea to discuss resuscitation with patients and families and to have more structured, person centred plans, goals, and limitations of treatment, using processes such as ReSPECT $^{1}$ or advance care plans ${ }^{23}$ for people with long term conditions or frailty, including care home residents. The main push was to do more of this, for more people, more of the time-and hence to improve end of life care and avoid overmedicalisation of natural dying.

Already, it was good practice to avoid sending people from care homes into the bewildering environment of acute hospital beds, unless there was a very clear indication, and to try to provide healthcare treatment (including palliative care) in that familiar environment. ${ }^{45}$

Already, we had to make daily decisions about admission to intensive care units (ICUs) based not on crude chronological age, disability, or quality of life judgments but on the patient's ability to benefit versus the risk of harm and the competing needs of other potential patients. ${ }^{67}$ And we already used evidence based scoring systems and large, rolling datasets to help guide decision making. ${ }^{89}$

Already, we held it to be good practice to avoid hospital admission of people who didn't need the full facilities of a general hospital and to try to support them at home. And we already knew that hospitals running while rammed full-with overcrowding and long waits in the emergency department and stranded patients waiting weeks for community services-were bad for safety, quality, the patient experience, and the flow through beds..$^{10-12}$

\section{Established good practice}

During the pandemic, however, there's been a constant narrative in mainstream and social media that it's somehow bad-even scandalous-to discuss treatment limits, avoid admissions from care homes, provide palliative care for dying patients, consider carefully which patients may benefit from ICU admission, or run hospitals at lower bed occupancy.

Established practice is being portrayed as bad news. We've also seen the counter-phenomenon of problems that were plainly visible, but were largely ignored in mainstream media, suddenly becoming an issue.

The lack of pandemic preparedness after the 2017 flu pandemic report on Exercise Cygnus, like the lack of acute and ICU beds in relation to other countries, was there in plain sight. ${ }^{13}{ }^{14}$ There were also endemic problems in the capacity, funding, and staffing of social care-notably, care homes and their relative lack of consistent support from properly integrated local NHS services. ${ }^{15-17}$

Likewise, the, health policy think tanks and public health experts had repeatedly highlighted cuts to public health funding. ${ }^{18} 19$ These cuts have in turn impaired our ability to respond to this pandemic. Those same think tanks and nursing organisations had also repeatedly highlighted the decimation of the community nursing and health visiting workforce.

News values are what they are. But we need to stop reporting good practice as a bad thing-even in contentious areas such as care for the sickest or dying patients. And we should stop neglecting to report on issues affecting frail older people in community settings, which leaves them out of sight and out of mind.

Competing interests: See www.bmj.com/about-bmj/freelance-contributors. Provenance and peer review: Commissioned; not externally peer reviewed.

Fritz Z, Slowther A-M, Perkins GD. Resuscitation policy should focus on the patient, not the decision. BMJ 2017:356:j813. 10.1136/bmj.j813 28246084

2 Oliver D. David Oliver: Should advance care planning enter the mainstream?BMJ 2018;361:k2123. 10.1136/bmj.k2123 29764805

3 Royal College of Physicians. Talking about dying: How to begin honest conversations about what lies ahead. 19 Oct 2018. https://www.rcplondon.ac.uk/projects/outputs/talking about-dying-how-begin-honest-conversations-about-what-lies-ahead.

Oliver D. David Oliver: Reducing emergency admissions from care homes. BMJ 2019;367:I6149. 10.1136/bmj.l6149 31666225

5 British Geriatrics Society. Effective healthcare for older people living in care homes. Guidance on commissioning and providing healthcare services across the UK. Updated 6 Dec 2016. https://www.bgs.org.uk/resources/effective-healthcare-for-older-people-livingin-care-homes. 
6 National Institute for Health and Care Excellence. Acute and critical care. https://www. nice.org.uk/guidance/health-and-social-care-delivery/acute-and-critical-care.

7 Royal College of Physicians. NEWS2: supporting the physician's role in leading on the deteriorating patient. 17 Dec 2018. https://www.rcplondon.ac.uk/news/news2-supportingphysician-s-role-leading-deteriorating-patient.

$8 \mathrm{MD}+$ Calc.com. APACHE II score. https://www.mdcalc.com/apache-ii-score.

9 Intensive Care National Audit and Research Centre. Covid-19. https://www.icnarc.org/.

10 Healthcare Improvement Scotland. Care of older people in hospital standards. Jun 2015. http://www.healthcareimprovementscotland.org/our_work/standards_and_guidelines/ stnds/opah_standards.aspx.

11 British Geriatrics Society. The Silver Book-guidelines for the emergency care of older people. 21 Jun 2012. https://www.bgs.org.uk/blog/the-silver-book-guidelines-for-theemergency-care-of-older-people.

12 NHS. Acute Frailty Network. https://www.acutefrailtynetwork.org.uk/.

13 Doward J. Government under fire for failing to act on pandemic recommendations. Guardian $2020 \mathrm{Apr}$ 19. https://www.theguardian.com/world/2020/apr/19/governmentunder-fire-failing-pandemic-recommendations.

14 Prin $\mathrm{M}$, Wunsch $\mathrm{H}$. International comparisons of intensive care: informing outcomes and mproving standards. Curr Opin Crit Care 2012:18:700-6.
10.1097/MCC.0b013e32835914d5. https://www.ncbi.nlm.nih.gov/pmc/articles/ PMC3551445/. 22954664

15 Oliver D. David Oliver: A troubled care home market should concern us all. BMJ Opinion $2020 \mathrm{Mar}$ 4. https://blogs.bmj.com/bmj/2020/03/04/david-oliver-troubled-care-home-marketshould-concern-us-all/.

16 Nuffield Trust. Closing the gap: key areas for action on the health and care workforce. 21 Mar 2019. https://www.nuffieldtrust.org.uk/research/closing-the-gap-key-areas-for-actionon-the-health-and-care-workforce.

17 Bottery S. What's your problem, social care? The eight key areas for reform. King's Fund. 5 Nov 2019. https://www.kingsfund.org.uk/publications/whats-your-problem-social-care.

18 Health Foundation. Taking our health for granted: plugging the public health grant funding gap. Oct 2018. https://www.health.org.uk/publications/taking-our-health-for-granted.

19 Local Government Association. LGA responds to public health grant announcement. 17 Mar 2020. https://www.local.gov.uk/lga-responds-public-health-grant-announcement.

Published by the BMJ Publishing Group Limited. For permission to use (where not already granted under a licence) please go to http://group.bmj.com/group/rights-licensing/ permissions 